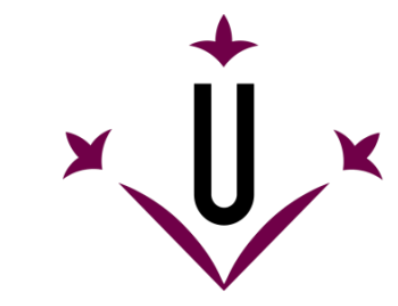

Universitat de Lleida

Document downloaded from:

http://hdl.handle.net/10459.1/69342

The final publication is available at:

https://doi.org/10.1016/j.lwt.2020.109877

Copyright

cc-by-nc-nd, (c) Elsevier, 2020 
3

\section{Fate of the mycotoxins in the wort and yeast during ale and lager fermentation and their evaluation under different technological parameters}

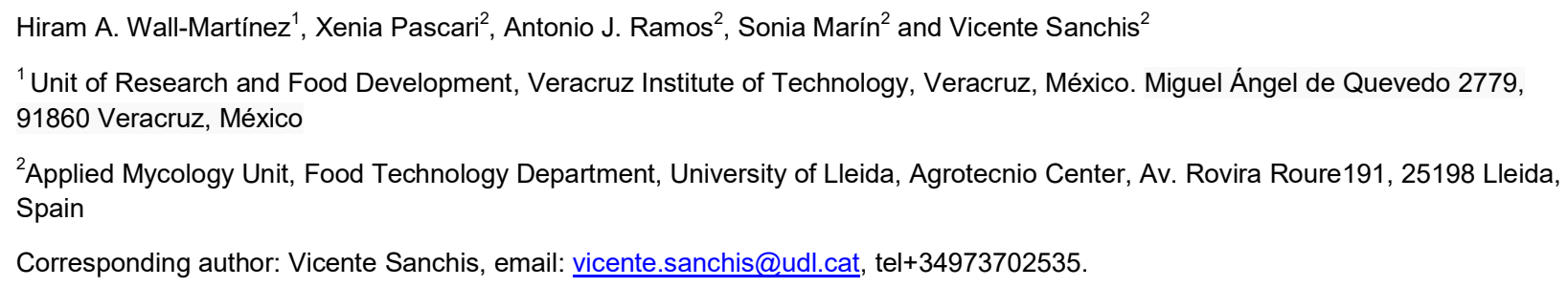

\section{ABSTRACT}

This study aimed to evaluate the mycotoxins transfer in the wort and yeast during ale and lager fermentation, secondary fermentation, and beer storage. Four yeasts were used to ferment wort contaminated with DON and ZEN. The wort was fermented with two $S$. cerevisiae yeasts (yeasts $A$ and B) at $15,20,25{ }^{\circ} \mathrm{C}$ for $96 \mathrm{~h}$, and two S. pastorianus (yeasts $\mathrm{C}$ and D) at 10, 15, $20{ }^{\circ} \mathrm{C}$ for $144 \mathrm{~h}$. After fermentation, the two wort with the highest mycotoxin decrease were selected for a second fermentation and stored period. Mycotoxins were extracted using QuEChERS and analyzed by UHPLC-DAD/FLD. In the wort, DON decreased from $11 \%$ to $27 \%$, locating it adsorbed on the yeast from LOD to $6.16 \%$. ZEN in the wort decreased from $29 \%$ to $90 \%$, locating it adsorbed on the yeast from $5.41 \%$ to $33.86 \%$. Alefermentation process obtained the highest decrease of ZEN in the wort, whereas, for DON, there was no significant difference in the reduction between the 2 fermentation styles. Finally, there was no significant change in mycotoxin content during storage. Knowledge of the mitigating effect of fermentation variables could help to reduce the mycotoxin content in beer.

Key words: Deoxynivalenol; zearalenone; Saccharomyces yeast; Secondary fermentation; Beer 
30 The mycotoxins produced by Fusarium species are characterized by a high chemical and physical 31 stability and are not eliminated by technological treatments, thus a transfer from raw materials to beer is possible (Rodríguez-Carrasco, Fattore, Albrizio, Berrada, \& Mañes, 2015). Mycotoxin detoxification is

33 typically achieved by removal or elimination of the contaminated elements or by total or partial inactivation 34 of the toxins present in these products. In addition to physical and chemical methods, biological methods have proved to be an efficient option for the detoxification of mycotoxins (Vila-Donat, Marín, Sanchis, \&

36 Ramos, 2018).

37 Recent surveys have shown the presence of low concentrations of mycotoxins, mainly deoxynivalenol (DON), deoxynivalenol-3-glucoside(DON-3-Glc), zearalenone (ZEN) and fumonisins (FBs) in commercial 39 beers from different countries (Pascari, Ortiz-Solá, Marín, Ramos, \& Sanchis, 2018; Peters et al., 2017; 40 Wall-Martínez, Pascari, Ramos, Marín, \& Sanchis, 2019). Our research group has analyzed the fate of 41 Fusarium mycotoxins during beer production processes such as malting (Pascari, Gil-Samarra, Marín, 42 Ramos, \& Sanchis, 2019) and mashing (Pascari, Rodriguez-Carrasco, et al., 2019), (i) identifying its 43 decrease during steeping, (ii) confirming its conversion to DON-3-Glc during germinationand (iii) its 44 transfer to the wort after the first stage of the mashing process.

45 Beer fermentation process is initiated by two main yeast strains $S$. cerevisiae, in the case of ale or top46 fermented beers and S. pastorianus, in the case of lager or bottom-fermented beers. Their metabolic 47 activity is possible between 5 and $30^{\circ} \mathrm{C}$. Sometimes, in the search for a more unique flavour of the beer, 48 the brewer might decide to perform a secondary fermentation. This is usually the case for lager beers, 49 and from the technological perspective, it is a difficult task as it implies a higher risk of contamination with 50 altering bacteria (Kunze, 2006).

51 Wall-Martínez, Pascari, Bigordà, et al. (2019) evaluated the effect of 15 commercial yeasts (S. cerevisiae 52 and S. pastorianus) in the mitigation of DON and ZEN during beer fermentation at $20{ }^{\circ} \mathrm{C}$ for all the yeast 53 strains tested and at a single mycotoxin concentration. Fusarium mycotoxins were extracted with 54 immunoaffinity columns specific to each mycotoxin and analysed with UHPLC-FLD/DAD. At the end of 55 the fermentation process, $10-17 \%$ of DON and $30-70 \%$ of ZEN were removed, of which up to $6 \%$ of 
the initial concentration of DON and $31 \%$ of the ZEN were adsorbed to the yeast cell. Garda et al. (2005)

57 reported a reduction of $53 \%$ in malt spiked with DON; however, Nathanail et al. (2016) observed a $15 \%$ reduction of DON content in the wort at the end of the alcoholic fermentation. The wide variation between the results obtained in the three studies could be due to the use of different fermentation parameters, mycotoxin content, or yeast strains that could have had different adsorption potential.

61 The increasing awareness of the food industry regarding the mycotoxins shows the need of developing analytical methods that are faster, greener, more precise, and guarantee the quality, authenticity, safety, and traceability of target compound in a diversity of sample matrices (Souza-Silva, Gionfriddo, \&

64 Pawliszyn, 2015). In this context, QuEChERS method is one of the most promising and user-friendly during the mycotoxin extraction, involving reduced sample amounts and organic solvents (Perestrelo et al., 2019). This study aimed to evaluate the fate of DON and ZEN in the wort and the yeast during ale and

67 lager fermentation, secondary fermentation, and storage using the QuEChERS method. Also, their fate under different technological parameters was evaluated.

\section{Materials and methods}

\section{$71 \quad 2.1$ Reagents and chemical}

72 Water was obtained from a Milli- $Q^{\circledR}$ Reagent from Millipore Corp (Brussels, Belgium). Methanol and 73 acetonitrile were purchased from Scharlab (Sentmenat, Spain). Mycotoxin standards were purchased 74 from Romer Labs (Tulln, Austria). Immunoaffinity columns for DON and ZEN were purchased from R75 Biopharm (Glasgow, UK). C18 was purchased from Phenomenex (Torrance, USA), Magnesium sulfate 76 heptahydrate was acquired from Probus SA (Badalona, Spain) and agar powder from VWR Prolabo 77 (Leicestershire, UK), PBS was prepared with potassium chloride $(0.2 \mathrm{~g})$ (Panreac, Castellar del Vallès, 78 Spain), potassium dihydrogen phosphate $(0.2 \mathrm{~g})$ (Castellar del Vallès, Spain), disodium phosphate 79 anhydrous (1.16 g) (Castellar del Vallès, Spain) and sodium chloride (8.0 g) (Fisher Bioreagents, New 80 Jersey, USA) in $1 \mathrm{~L}$ of Milli-Q water. YEPD was prepared with $10 \mathrm{~g} / \mathrm{L}$ of yeast extract powder (Bacto,

81 Madrid, Spain), $20 \mathrm{~g} / \mathrm{L}$ of peptone, $20 \mathrm{~g} / \mathrm{L}$ of glucose (Fisher chemical) and $20 \mathrm{~g} / \mathrm{L}$ of agar.Yeasts were 82 purchased from www.cervezasdelmundo.com. 


\subsection{Preparation of mycotoxin solutions}

84 DON and ZEN concentration in the stock solution was checked by UV spectroscopy according to AOAC,

85 Chapter 49. Standard solutions of DON and ZEN were prepared in methanol at a concentration of $8610 \mathrm{mg} / \mathrm{mL}$ and stored at $4{ }^{\circ} \mathrm{C}$. Calibration curves were prepared by appropriate dilution of the stock 87 solution with the mobile phase.

\subsection{DON and ZEN contamination of malted barley}

Barley (Hordeum vulgare) was supplied by a malting plant (La Moravia, Spain) in September 2018. The absence of DON and ZEN in the malt was verified by UHPLC-DAD/FLD. A control batch of malted barley was used to prepare control wort (absence of DON and ZEN); while, another malt batch was contaminated using a toxigenic strain of Fusarium graminearum (F.46) obtained from the collection of strains of the Food Technology Department of the University of Lleida, Spain. The grains were disinfected according to Andrews et al. (1997). Briefly, $500 \mathrm{~g}$ of grains was submerged into $0.4 \mathrm{~g} / 100 \mathrm{~mL}$ sodium hypochlorite solution for $2 \mathrm{~min}$ and then abundantly rinsed twice with sterile distilled water. Then, the grains were placed in hermetically closed sterile ISO bottles and left overnight at $4{ }^{\circ} \mathrm{C}$ with a small amount of water to allow the water activity to reach a value close to 0.99 (Aqualab Series, Washington, USA). Malted barley was transferred to Petri dishes and $1 \mathrm{~mL}$ of a spore suspension of $F$. graminearum was transferred to each dish. Petri dishes were incubated at $25{ }^{\circ} \mathrm{C}$ for 30 days. The final mycotoxin concentration in the contaminated malt was $4600 \mu \mathrm{g} / \mathrm{kg}$ and $2800 \mu \mathrm{g} / \mathrm{kg}$ for DON and ZEN, respectively.

\subsection{Yeast}

Four freeze-dried yeasts strains of various commercial brands, 2 Saccharomyces cerevisiae (ale fermentation, code A and B) and 2 Saccharomyces pastorianus (lager fermentation, code C and D), who presented the highest adsorption of mycotoxins in study by Wall-Martínez, Pascari, Bigordà, et al. (2019) were used to ferment the wort.

\subsection{Wort production}

Three batches of wort with different mycotoxin concentration were made. Control wort (prepared from uncontaminated malt), the low mycotoxin contaminated, and the high mycotoxin contaminated. 
Contaminated batches were made by mixing different portions of contaminated and uncontaminated

110 malted grain. Maceration was carried out by mixing $2.5 \mathrm{~L}$ of deionized water with $500 \mathrm{~g}$ of malted barley

111 (previously coarse ground) and then maintaining the mix for $15 \mathrm{~min}$ at $45^{\circ} \mathrm{C}$, followed by 60 min at $65^{\circ} \mathrm{C}$,

112 ending with $72{ }^{\circ} \mathrm{C}$ for another $15 \mathrm{~min}$. The wort was decanted, the density was adjusted to $1005-1010$

$113 \mathrm{~kg} / \mathrm{m}^{3}$ with deionized water and the hop was added (10g/L). The wort was boiled for approximately $2 \mathrm{~h}$ (up

114 to a density of $1050 \mathrm{~kg} / \mathrm{m}^{3}$ ) and stored in sterile bottles until fermentation.

\subsection{Primary fermentation, secondary fermentation and storage}

116 First fermentation assays were performed at $250 \mathrm{~mL}$ scale. To each yeast, three fermentation 117 temperatures were used: 15,20 , and $25^{\circ} \mathrm{C}$ for high-ale fermentation using $\mathrm{S}$. cerevisiae and 10,15 , and $11820^{\circ} \mathrm{C}$ for low-lager fermentation using S. pastorianus. Yeast concentration was prepared at $10^{6} \mathrm{CFU} / \mathrm{mL}$ 119 for all the wort samples, initial count was verified using a Thoma cell counter chamber. Sampling was 120 performed daily in the following time points: $24,48,72$, and $96 \mathrm{~h}$ for fermented wort with $\mathrm{S}$. cerevisiae and $12124,48,72,96,120$ and $144 \mathrm{~h}$ for fermented wort with S. pastorianus. The two treatments of each yeast 122 species (ale or lager) with the highest mycotoxin reduction in the wort were selected for a second 123 fermentation. The double or second fermentation was carried out at $20^{\circ} \mathrm{C}$ samples being taken at the end 124 of the process $(96 \mathrm{~h})$ in both wort and yeast. The double fermented wort was distributed in 4 bottles of 50 $125 \mathrm{~mL}$ for the storage analysis. Every week a $30 \mathrm{~mL}$ sample was collected from each bottle for 4 weeks, and 126 the remainder wort was discarded.

127 Control wort was fermented for all temperatures and yeasts included in the research for the first and 128 second fermentation. At each sampling point, three samples were collected. The first sample (10 $\mathrm{mL})$ was 129 used to determine the $\mathrm{pH}$ and alcohol content (portable densimeter DMA, Anton Paar). The second 130 sample $(30 \mathrm{~mL})$ was used to determine mycotoxin content and the third sample $(1 \mathrm{~mL})$ was diluted from $13110^{-1}$ to $10^{-8}$ with PBS. Then $100 \mu \mathrm{L}$ of $10^{-6}, 10^{-7}$ and $10^{-8}$ dilutions was superficially spread on YEPD agar 132 medium dishes and incubated at $25^{\circ} \mathrm{C}$. After $48 \mathrm{~h}$ the yeast growth was calculated. At the end of every 133 fermentation, yeast was separated from the remaining wort by centrifugation at $1869 \times \mathrm{g}$ for $10 \mathrm{~min}$, 134 lyophilized, and weighted. All samples were stored at $-18^{\circ} \mathrm{C}$ until UHPLC analysis.

\section{$135 \quad 2.7$ DON and ZEN extraction in malt}


Extraction in malt was performed following R-Biopharm instructions. For DON, five grams of ground

137 sample was mixed with $1 \mathrm{~g}$ of sodium chloride and $40 \mathrm{~mL}$ of Mili $\mathrm{Q}$ water followed by 30 min stirring. Then,

138 samples were centrifuged for $10 \mathrm{~min}$ at $1846 \mathrm{x}$ g. Supernatant was filtered through a glass microfiber

139 paper filter (Whatman, Maidstone, UK) and $2 \mathrm{~mL}$ of the filtrate was passed through the column. The

140 immunoaffinity column was then washed with $10 \mathrm{~mL}$ of bi-distilled water and the toxins were eluted with

$1413 \mathrm{~mL}$ HPLC-grade methanol (1.5 mL performing back-flushing and $1.5 \mathrm{~mL}$ for the final elution).

142 For ZEN, five grams of ground sample was mixed with $25 \mathrm{~mL}$ of extraction solvent acetonitrile: distillated 143 water $(75: 25, v / v)$ and stirred for $30 \mathrm{~min}$. Samples were centrifuged for $10 \mathrm{~min}$ at $1846 \times \mathrm{g}$ and $10 \mathrm{~mL}$ of 144 supernatant was mixed with $40 \mathrm{~mL}$ of PBS at $\mathrm{pH}$ of 7.4 The obtained $50 \mathrm{~mL}$ was passed through the 145 immunoaffinity column which was afterwards washed with $20 \mathrm{~mL}$ of PBS. ZEN was eluted with $3 \mathrm{~mL}$ of 146 acetonitrile ( $1.5 \mathrm{~mL}$ performing back-flushing and $1.5 \mathrm{~mL}$ for the definite elution).

\section{$147 \quad 2.8$ QuEChERS extraction to beer samples}

148 DON and ZEN extraction in fermented wort was processed as Rodríguez-Carrasco et al. (2015) with 149 slight modifications. Briefly, $6 \mathrm{~mL}$ of beer sample was added to $14 \mathrm{~mL}$ of acetonitrile and vigorously 150 shaken for $60 \mathrm{~s}$ prior the addition of $4 \mathrm{~g}$ of anhydrous $\mathrm{MgSO}_{4}$ and $1 \mathrm{~g} \mathrm{NaCl}$ after which it was agitated at $1511846 \times \mathrm{g}$ in an orbital rotary shaker (Infors AG CH-4103, Bottmingen, Switzerland) after 30 min the 152 mixture was centrifugated for $8 \mathrm{~min}$ at $1869 \times \mathrm{g}$. Then, the acetonitrile extract was submitted to a 153 dispersive solid phase extraction into a tube containing $900 \mathrm{mg} \mathrm{MgSO}_{4}$ and $300 \mathrm{mg} \mathrm{C} 18$, it was vortexed 154 for $1 \mathrm{~min}$ and centrifuged for $8 \mathrm{~min}$ at $1846 \mathrm{x} \mathrm{g}$.

\subsection{DON and ZEN extraction in yeast}

156 The DON and ZEN extraction in yeast was performed according to the method described by 157 Campagnollo et al., 2015. Two hundred milligrams of lyophilized yeast were suspended in $2 \mathrm{~mL}$ of $0.1 \mathrm{M}$ 158 potassium phosphate buffer $\mathrm{pH} 6.5$, mixed on a rotating shaker (Bottmingen, Switzerland) for 60 min at $15925^{\circ} \mathrm{C}$ and sonicated for 15 min (Brason 2800). The samples were centrifuged (Eppendorf, Hamburg, 160 Germany) at $1846 \times \mathrm{g}$ for $10 \mathrm{~min}$ and $0.8 \mathrm{~mL}$ of the supernatant was removed and analyzed by UHPLC. 161 Control samples (200 mg of yeast in buffer solution) were also prepared and analyzed.

\subsection{Sample preparation.}


All extracted samples (except yeast extracts) were evaporated under a low nitrogen stream at $40^{\circ} \mathrm{C}$,

164 extracts were resuspended in $1 \mathrm{~mL}$ of mobile phase. The obtained extract was filtered with nylon filter $165(0.4 \mu \mathrm{m})$ before being injected $(50 \mu \mathrm{L})$ to the UHPLC DAD/FLD. All the samples were analyzed by 166 triplicate.

\section{$167 \quad 2.11 \quad$ UHPLC system}

168 An Agilent Technologies 1260 Infinity UHPLC system (California, USA) coupled with an Agilent 1260 169 Infinity II Diode Array Detector (DAD) and Agilent 1260 Infinity Fluorescence Detector (FLD) was used. 170 Separation was achieved on a Gemini ${ }^{\circledR} \mathrm{C} 18$ column from Phenomenex $150 \times 4.6 \mathrm{~mm}, 5 \mu \mathrm{m}, 110 \AA$ 171 (California, USA). For DON analysis, the absorption wavelength was setup at $220 \mathrm{~nm}$. The mobile phase 172 was composed of methanol:acetonitrile:water Mili Q $(5: 5: 90, \mathrm{v} / \mathrm{v} / \mathrm{v})$ and set at a flow rate of $1 \mathrm{~mL} / \mathrm{min}$. ZEN 173 detection and quantification was performed at $274 \mathrm{~nm}$ and $455 \mathrm{~nm}$ excitation and emission wavelengths, 174 respectively. The mobile phase was acetonitrile:Milli $\mathrm{Q}$ water $(60: 40, v: v)$ with $\mathrm{pH}$ adjusted at 3.2 175 with glacial acetic acid. Flow rate was set at $0.6 \mathrm{~mL} / \mathrm{min}$.

176 The column temperature was $40^{\circ} \mathrm{C}$, the injection volume was $50 \mu \mathrm{L}$ and total run time was 20 min for the 177 analysis of both DON and ZEN.

\section{$178 \quad 2.12 \quad$ Validation of analytical methods}

179 Selectivity was checked by injecting $50 \mu \mathrm{L}$ of standard solution for at least three times, comparing 180 retention time and peak resolution between injections. For linearity check, a calibration curve of eight 181 concentration levels for each toxin $(20,30,50,100,250,500,1000,3000 \mu \mathrm{g} / \mathrm{L}$ for DON and $30,50,100$, $182300,500,1000,1500,3000 \mu \mathrm{g} / \mathrm{L}$ of ZEN solutions) was prepared and injected into the system, generating 183 a linear regression plotting solutions concentration versus peak area.

184 Precision was evaluated preparing blank wort samples spiked $\mu \mathrm{g} / \mathrm{kg}$ with DON and ZEN at concentration 185 levels $(75,250$ and $1000 \mu \mathrm{g} / \mathrm{kg})$ and percentages recovery were determined. The validation parameters 186 are shown in Table 1. 
187 The recovery percentages using the QuEChERS method were similar to those made in previous works 188 (Wall-Martínez, Pascari, Bigordà, et al., 2019) using immunoaffinity columns and the same HPLC system. 189 The RSD was below $10 \%$.

190 The recovery and relative standard deviation levels in yeast were previously described in Wall-Martínez,

191 Pascari, Bigordà, et al. (2019) $67-71 \%$ for DON and 73-80 \% for ZEN. The limit of detection (LOD) was 192 considered as three times the signal to noise ratio. Method performance was assessed according to 193 Commission Regulation (EC) 401/2006 (European Commission, 2006).

\section{$194 \quad 2.13 \quad$ Statistical Analysis}

195 All the experiments results were represented as the average of triplicate tests and expressed as 196 mean \pm standard deviation. Statistical evaluations were performed by one-way analysis of variance 197 (ANOVA) and Tukey test $(p=0.05)$ using Minitab 18 software.

\section{Results and discussion}

\subsection{Characteristics of the wort}

201 Relative density and $\mathrm{pH}$ of the wort were $1.040 \mathrm{~g} / \mathrm{cm}^{3}$ and 4.96, respectively. Mycotoxin contamination 202 was $1164 \pm 57 \mu \mathrm{g} / \mathrm{kg}$ for DON and $440 \pm 16 \mu \mathrm{g} / \mathrm{kg}$ for ZEN in high contaminated wort and $560 \pm 49 \mu \mathrm{g} / \mathrm{kg}$ 203 for DON and $284 \pm 14 \mu \mathrm{g} / \mathrm{kg}$ for ZEN in low contaminated wort. DON and ZEN levels in control wort were 204 below the detection limits.

\subsection{Alcohol produced}

206 The DON and ZEN concentration in wort had no significant effect on the $\mathrm{pH}$, yeast growth or alcohol 207 produced. It is known that temperature affects the population dynamics of Saccharomyces strains during 208 alcoholic fermentation (Charoenchai, Fleet, \& Henschke, 1998; Torija, Rozès, Poblet, Guillamón, \& Mas, 209 2003). The growth rate of yeasts was 3 logarithmic units, except for the treatments with lower 210 fermentation temperatures $\left(15^{\circ} \mathrm{C}\right.$ for S. cerevisiae and $10^{\circ} \mathrm{C}$ for S. pastorianus), which was of 2 211 logarithmic units, decreasing the alcohol production in the wort at the end of the fermentation. 
212 The results of the present work are aligned with the published literature confirming that the presence of 213 mycotoxins in the wort did not have any impact on the fermentation process compared to the control 214 sample.

215 The previous results suggest that beer producers should pay primary attention to the content of 216 mycotoxins in the raw material since mycotoxin contamination in the wort does not affect the 217 physicochemical characteristics regularly measured (alcohol content, $\mathrm{pH}$, growth of yeasts) in the final 218 product.

\subsection{Effect of temperature and mycotoxin concentration in DON reduction during primary} fermentation

221 The fate of DON during beer fermentation using S. cerevisiae ale and S. pastorianus lager yeasts is 222 shown in Table 2.

223 DON content decreased between $11 \%$ and $27 \%$ in fermented wort with S. cerevisiae and from $14 \%$ to $22425 \%$ in fermented wort with S. pastorianus, reaching a higher decrease than Nathanail et al. (2016) (15 $225 \%$ ) and Wall-Martínez, Pascari, Bigordà, et al. (2019) (from $2 \%$ to $17.5 \%$ ) have reported. The mycotoxin 226 concentration in wort had no influence on DON rate reduction. The higher temperatures of fermentation $227\left(25{ }^{\circ} \mathrm{C}\right.$ and $20{ }^{\circ} \mathrm{C}$ for S. cerevisiae and $20{ }^{\circ} \mathrm{C}$ and $15{ }^{\circ} \mathrm{C}$ for S. pastorianus) were characterized by the 228 higher rate of DON adsorption to the yeast. This could be attributed to the low growth rate of 229 Saccharomyces yeast metabolism at low fermentation temperatures (Charoenchai et al., 1998), reducing 230 the biodegradative effect and the adsorption sites actives of $\beta$-glucans from the cell walls (Huwig, 231 Freimund, Käppeli, \& Dutler, 2001; Shetty \& Jespersen, 2006).

232 Both yeast strains of S. cerevisiae (A and B codes) showed approximately $3 \%$ of initial DON content 233 adsorbed at the yeast cell but only at the higher temperatures $\left(20\right.$ and $\left.25^{\circ} \mathrm{C}\right)$. It could be explained by a 234 higher cell mass accumulated during the fermentation process at these temperatures compared to the 235 lower temperatures. S. pastorianus (codes C and D) registered an absorption of 4 to $6 \%$ of DON to the 236 yeast cells. This result was achieved at both $15^{\circ} \mathrm{C}$ and $20^{\circ} \mathrm{C}$ in the case of the yeast $\mathrm{C}$, and only at $20^{\circ} \mathrm{C}$ 237 in the case when yeast D was used. The highest adsorption of DON in yeast after fermentation was 238 detected using S. pastorianus at $20{ }^{\circ} \mathrm{C}$ (yeast C), moreover, this treatment was the only condition where 
DON was detected $(34.44 \pm 1.34 \mu \mathrm{g} / \mathrm{kg})$ in wort with a low initial level of mycotoxin, this could be because DON adsorption of other treatments would be below LOD $(20 \mu \mathrm{g} / \mathrm{kg})$. Furthermore, it can be seen from

241 Table 2 that the total concentration that was identified in the beer and in the yeast residues suggests that 242 approximately $20 \%$ of toxin could be biodegraded to modified DON forms, mainly, DON3G, 3 ADON, or 243 15ADON (Lancova et al., 2008). Also, these mycotoxins forms have been detected in recent beer 244 surveys (Pascari et al., 2018; Peters et al., 2017; Wall-Martínez, Pascari, Ramos, et al., 2019). 245 Nonetheless, the available analytical technique did not allow us to confirm this statement.

\subsection{Effect of temperature and mycotoxin concentration in ZEN reduction during primary fermentation}

247 The fate of ZEN during beer fermentation using Saccharomyces cerevisiae ale and Saccharomyces 248 pastorianus lager yeasts is shown in Table 3.

249 The decrease of ZEN was between $29 \%$ and $90 \%$ in fermented wort with S. cerevisiae and between 39 $250 \%$ and $67 \%$ for fermented wort with S. pastorianus, reaching a higher decrease than the level reported by 251 Wall Martínez et al. (2019) (31-72\%). As in the case of DON, higher fermentation temperatures $\left(25^{\circ} \mathrm{C}\right.$ 252 for $S$. cerevisiae and $20^{\circ} \mathrm{C}$ and $15{ }^{\circ} \mathrm{C}$ for S. pastorianus) favored ZEN reduction in the wort, and this 253 process conditions led to the highest concentrations of ZEN in the yeast at the end of fermentation. Unlike 254 DON, ZEN was detected in yeasts at the end of fermentation on high and low levels of mycotoxin in the contaminated wort, this may be because the LOD for ZEN is lower than for DON. Similar to Wall-Martínez et al. (2019) with 4 to $31 \%$ ZEN retained by $S$. cerevisiae and 7.5-15\% of ZEN retained by $S$. 257 pastorianus; however, relatively different from the values reported by Campagnollo et al. (2015) (75\% of 258 binding in S. cerevisiae in vitro test), ZEN was detected from 5 to $33 \%$ in S. cerevisiae and from 10 to 25 $259 \%$ in S. pastorianus yeast. According to the fermentation parameters used there was between 20 and 50

$260 \%$ of ZEN that was not recovered in wort or yeast. It would be relevant to determine the co-occurrence of 261 some masked mycotoxins such as $\beta$-zearalenol ( $\beta$-ZEL), $\alpha$-zearalenol ( $\alpha-Z E L)$ to identify if fermentation is 262 an appropriate process for mitigation of ZEN or if it was biodegraded or metabolized to a form modified as 263 suggested by several authors (Keller et al., 2015; Mizutani, Nagatomi, \& Mochizuki, 2011). 
The mycotoxin content in fermented beer and yeast during double fermentation and beer storage is shown in Table 4.

267 This is the first study of mycotoxin analysis during secondary fermentation and storage. At the end of the second fermentation, mycotoxin content in the wort was reduced in proportions like the first fermentation (15\% for DON and $44-50 \%$ for ZEN). The mycotoxin adsorbed by the yeast was also in quantities similar to the first fermentation ( $5 \%$ of DON and $21-27 \%$ of ZEN). On the other hand, no significant difference

271 was found in mycotoxins content of the double fermented wort after four weeks of storage. The total 272 reduction of mycotoxins including primary, secondary fermentation, and storage were between $27.52 \%$ 273 and $37.65 \%$ for DON and $79.66 \%$ and $83.30 \%$ for ZEN.

\subsection{Influence of fermentation style on the reduction of mycotoxins in primary fermented wort}

275 The characteristics of primary fermented wort with Saccharomyces yeasts at different temperatures are 276 show in the Table 5.

277 The mycotoxin presence in the wort had no effect on the growth of Saccharomyces yeast used; 278 consequently, it did not influence the alcohol production at the end of two fermentation beer styles. Lower 279 fermentation temperatures resulted in lower DON adsorption in the yeasts. There was no significant 280 difference between the DON reduction when the wort is fermented with S. cerevisiae compared to the

281 fermentation by S. pastorianus strains. This could be because the reduction occurs mainly in the first $24 \mathrm{~h}$ 282 of the fermentation, which is the reason why the difference in fermentation times could not influence. Ale 283 fermentation at $25^{\circ} \mathrm{C}$ was the process with the highest ZEN decrease in wort and the highest content of it 284 found in yeast residue. Low fermentation temperatures affect the adsorption of ZEN to S. cerevisiae, 285 while there was no significant effect in the ZEN absorbed in S. pastorianus yeast after the fermentation. 286 Depending on fermentation variables, DON decrease in wort can be up to $14 \%$, while for ZEN up to 80

$287 \%$. This reduction could explain the result of the studies of Pascari et al., 2018; Peters et al., 2017; Wall288 Martínez, Pascari, Ramos, et al., 2019 who detected traces of ZEN and diverse concentrations of DON 289 and its modified forms in beers of different styles in different countries. It is relevant to know the 290 fermentation variables effect in the mitigation of mycotoxins because it can considerably reduce the 291 mycotoxin intake for beer consumption. 


\section{Conclusion}

294 The DON and ZEN decrease in yeast and fermented wort with different conditions process was analyzed. Mycotoxins concentration in wort had no effect on the ethanol production, growth rate of 296 yeasts or DON and ZEN degradation during fermentation. In addition to the yeast growth and alcohol 297 production, for DON, the fermentation temperature had an influence on mycotoxin decrease in wort and mycotoxin adsorption to the yeast. For ZEN, temperature only had influence in the mycotoxin adsorption on yeast. A second fermentation contributes to the reduction of mycotoxin levels in similar proportions as the first fermentation. Regarding the fermentation style, ale fermentation favored the adsorption of ZEN to $S$. cerevisiae cells and lager fermentation favored the adsorption of DON to S. pastorianus cells. The choice of adequate parameters is relevant to decrease the mycotoxin content during beer fermentation. A second fermentation would be a real option to decrease the mycotoxin content in previously fermented wort, ensuring that the yeast with adsorbed mycotoxin is removed from the final product. The use of QuEChERS as a method to extract mycotoxins obtained retention percentages similar to those obtained by immunoaffinity columns, with some advantages such as shorter extraction time, lower supplies cost,

307 in addition to requiring a single extraction for both mycotoxins (DON and ZEN).

Campagnollo, F. B., Franco, L. T., Rottinghaus, G. E., Kobashigawa, E., Ledoux, D. R., Daković, A., \&

Andrews, S., Pardoel, D., Harun, A., \& Treloar, T. (1997). Chlorine inactivation of fungal spores on cereal 5. References

Charoenchai, C., Fleet, G. H., \& Henschke, P. A. (1998). Effects of temperature, pH, and sugar concentration on the growth rates and cell biomass of wine yeasts. American Journal of Enology and Viticulture, 49(3), 283-288. 
maximum levels for certain contaminants in foodstuffs. Official Journal of the European Communitites, L364(1881), 5-24. https://doi.org/10.2203/dose-response.06-012.Hanekamp

Garda, J., Martins Macedo, R., Faria, R., Bernd, L., Dors, G. C., \& Badiale-Furlong, E. (2005). Alcoholic fermentation effects on malt spiked with trichothecenes. Food Control, 16(5), 423-428. https://doi.org/10.1016/j.foodcont.2004.05.001

Huwig, A., Freimund, S., Käppeli, O., \& Dutler, H. (2001). Mycotoxin detoxication of animal feed by different adsorbents. Toxicology Letters, 122(2), 179-188. https://doi.org/10.1016/S03784274(01)00360-5

Keller, L., Abrunhosa, L., Keller, K., Rosa, C. A., Cavaglieri, L., \& Venâncio, A. (2015). Zearalenone and its derivatives $\alpha$-zearalenol and $\beta$-zearalenol decontamination by Saccharomyces cerevisiae strains isolated from bovine forage. Toxins, 7(8), 3297-3308. https://doi.org/10.3390/toxins7083297

Kunze, W. (2006). Tecnología para Cerveceros Y Malteros. Retrieved from www.ame-kulessa.de

Lancova, K., Hajslova, J., Poustka, J., Krplova, A., Zachariasova, M., Dostalek, P., \& Sachambula, L. (2008). Transfer of Fusarium mycotoxins and 'masked' deoxynivalenol (deoxynivalenol-3-glucoside) from field barley through malt to beer. Food Additives \& Contaminants: Part A, 25(6), 732-744. https://doi.org/10.1080/02652030701779625

Mizutani, K., Nagatomi, Y., \& Mochizuki, N. (2011). Metabolism of zearalenone in the course of beer fermentation. Toxins, 3(2), 134-141. https://doi.org/10.3390/toxins3020134

Nathanail, A. V., Gibson, B., Han, L., Peltonen, K., Ollilainen, V., Jestoi, M., \& Laitila, A. (2016). The lager yeast Saccharomyces pastorianus removes and transforms Fusarium trichothecene mycotoxins during fermentation of brewer's wort. Food Chemistry, 203, 448-455. https://doi.org/10.1016/j.foodchem.2016.02.070

Pascari, X., Gil-Samarra, S., Marín, S., Ramos, A. J., \& Sanchis, V. (2019). Fate of zearalenone, deoxynivalenol and deoxynivalenol-3-glucoside during malting process. Lwt, 99, 540-546. https://doi.org/10.1016/j.Iwt.2018.10.030

Pascari, X., Ortiz-Solá, J., Marín, S., Ramos, A. J., \& Sanchis, V. (2018). Survey of mycotoxins in beer and exposure assessment through the consumption of commercially available beer in Lleida, Spain. Lwt, 92, 87-91. https://doi.org/10.1016/j.lwt.2018.02.021

Pascari, X., Rodriguez-Carrasco, Y., Juan, C., Mañes, J., Marin, S., Ramos, A. J., \& Sanchis, V. (2019). Transfer of Fusarium mycotoxins from malt to boiled wort. Food Chemistry, 278, 700-710. https://doi.org/10.1016/j.foodchem.2018.11.111

Perestrelo, R., Silva, P., Porto-Figueira, P., Pereira, J. A. M., Silva, C., Medina, S., \& Câmara, J. S. 
(2019). QuEChERS - Fundamentals, relevant improvements, applications and future trends.

Peters, J., Van Dam, R., Van Doorn, R., Katerere, D., Berthiller, F., Haasnoot, W., \& Nielen, M. W. F. (2017). Mycotoxin profiling of 1000 beer samples with a special focus on craft beer. PLoS ONE, 12(10), 1-27. https://doi.org/10.1371/journal.pone.0185887

Rodríguez-Carrasco, Y., Fattore, M., Albrizio, S., Berrada, H., \& Mañes, J. (2015). Occurrence of Fusarium mycotoxins and their dietary intake through beer consumption by the European population. Food Chemistry, 178(1881), 149-155. https://doi.org/10.1016/j.foodchem.2015.01.092

Shetty, P. H., \& Jespersen, L. (2006). Saccharomyces cerevisiae and lactic acid bacteria as potential mycotoxin decontaminating agents. Trends in Food Science and Technology, 17(2), 48-55. https://doi.org/10.1016/j.tifs.2005.10.004

Souza-Silva, É. A., Gionfriddo, E., \& Pawliszyn, J. (2015). A critical review of the state of the art of solidphase microextraction of complex matrices II. Food analysis. TrAC Trends in Analytical Chemistry, 71, 236-248. https://doi.org/10.1016/J.TRAC.2015.04.018

Torija, M. J., Rozès, N., Poblet, M., Guillamón, J. M., \& Mas, A. (2003). Effects of fermentation temperature on the strain population of Saccharomyces cerevisiae. International Journal of Food Microbiology, 80(1), 47-53. https://doi.org/10.1016/S0168-1605(02)00144-7

Vila-Donat, P., Marín, S., Sanchis, V., \& Ramos, A. J. (2018). A review of the mycotoxin adsorbing agents, with an emphasis on their multi-binding capacity, for animal feed decontamination. Food and Chemical Toxicology, 114, 246-259. https://doi.org/10.1016/j.fct.2018.02.044

Wall-Martínez, H. A., Pascari, X., Bigordà, A., Ramos, A. J., Marín, S., \& Sanchis, V. (2019). The fate of Fusarium mycotoxins (deoxynivalenol and zearalenone) through wort fermenting by Saccharomyces yeasts (S. cerevisiae and S. pastorianus). Food Research International, 126, 108587. https://doi.org/10.1016/j.foodres.2019.108587

Wall-Martínez, H. A., Pascari, X., Ramos, A. J., Marín, S., \& Sanchis, V. (2019). Frequency and levels of mycotoxins in beer from the Mexican market and exposure estimate for deoxynivalenol mycotoxins. Mycotoxin Research, 35(2), 207-216. https://doi.org/10.1007/s12550-019-00347-x 
Table 1. Validation parameters for the UHPLC/QuEChERS method for mycotoxins analysis in wort

\begin{tabular}{ccccc}
\hline Mycotoxin & $\begin{array}{c}\text { Spiking levels, } \\
\mu \mathrm{g} / \mathrm{kg}\end{array}$ & Replicates & $\begin{array}{c}\text { Recovery } \pm \text { SD } \\
(\%)\end{array}$ & $\begin{array}{c}\text { Inter day precision RSD } \\
(\%)\end{array}$ \\
\hline DON & 75 & 5 & $81.22 \pm 8.00$ & 6.50 \\
DON & 250 & 7 & $73.69 \pm 4.52$ & 3.33 \\
DON & 1000 & 5 & $83.87 \pm 4.92$ & 4.77 \\
ZEN & 75 & 5 & $85.63 \pm 11.44$ & 9.80 \\
ZEN & 250 & 7 & $84.44 \pm 11.60$ & 9.72 \\
ZEN & 1000 & 5 & $90.71 \pm 7.78$ & 7.06 \\
\hline
\end{tabular}

LOD DON: $20 \mu \mathrm{g} / \mathrm{kg}$, LOD ZEN: $2.5 \mu \mathrm{g} / \mathrm{kg}$.

SD: Standard deviation. RSD: Relative standard deviation. 
Table 2. DON in Saccharomyces yeasts and wort fermented at different temperatures

\begin{tabular}{|c|c|c|c|c|c|c|c|c|c|c|c|c|c|c|}
\hline \multirow{2}{*}{$\begin{array}{l}\text { Yeast } \\
\text { code }\end{array}$} & \multirow{2}{*}{$\begin{array}{c}\text { Temperature } \\
\left({ }^{\circ} \mathrm{C}\right)\end{array}$} & \multirow{2}{*}{$\begin{array}{c}\text { Initial } \\
\text { mycotoxin }\end{array}$} & \multicolumn{11}{|c|}{ DON in wort (\%) } & \multirow{2}{*}{$\begin{array}{c}\text { Yeast } \\
(\%)\end{array}$} \\
\hline & & & $24 \mathrm{~h}$ & & $48 \mathrm{~h}$ & & $72 \mathrm{~h}$ & & $96 \mathrm{~h}$ & & $120 \mathrm{~h}$ & & $144 \mathrm{~h}$ & \\
\hline$A$ & 15 & Low & 92.67 & a & 93.48 & a & 90.04 & a & 85.80 & a & NA & & NA & $<L O D$ \\
\hline A & 15 & High & 92.85 & a & $94.38^{a}$ & & 86.91 & a & 85.04 & a & NA & & NA & $<L O D$ \\
\hline A & 20 & Low & 84.08 & $a$ & $88.82^{a}$ & & 93.25 & $a^{+}$ & 81.88 & a & NA & & NA & $<L O D$ \\
\hline A & 20 & High & 85.47 & $a b$ & $71.80^{b}$ & & 72.74 & b & 78.72 & b & $\mathrm{NA}$ & & NA & $3.16 \pm 0.99$ \\
\hline A & 25 & Low & 76.92 & $a b$ & 67.30 & b & 76.61 & $a b$ & 76.89 & $a b$ & NA & & NA & $<L O D$ \\
\hline A & 25 & High & 82.51 & $a b$ & 70.29 & b & 65.87 & $\mathrm{~b}$ & 72.49 & b & NA & & NA & $2.13 \pm 0.17$ \\
\hline B & 15 & Low & 97.12 & $\mathrm{a}$ & 89.46 & a & 91.23 & a & 87.45 & a & NA & & NA & $<L O D$ \\
\hline B & 15 & High & 92.97 & $\mathrm{a}$ & 94.18 & a & 91.77 & a & 89.05 & a & NA & & NA & $<L O D$ \\
\hline B & 20 & Low & 83.39 & $a b$ & 85.75 & $\mathrm{ab}$ & 80.41 & $\mathrm{ab}$ & 75.38 & $\mathrm{~b}$ & $\mathrm{NA}$ & & NA & $<$ LOD \\
\hline B & 20 & High & 83.79 & a & 83.67 & a & 85.78 & a & 84.71 & a & $\mathrm{NA}$ & & $\mathrm{NA}$ & $2.89 \pm 0.49$ \\
\hline B & 25 & Low & 80.60 & $\mathrm{~b}$ & 79.31 & $\mathrm{~b}$ & 78.64 & b & 80.75 & b & NA & & NA & $<L O D$ \\
\hline B & 25 & High & 81.98 & $a b$ & 80.23 & $\mathrm{~b}$ & 78.77 & b & 77.38 & b & NA & & NA & $3.65 \pm 0.73$ \\
\hline C & 10 & Low & 97.18 & $\mathrm{a}$ & 96.05 & $a$ & 95.60 & a & 86.59 & a & 86.30 & a & $82.52^{a}$ & $<L O D$ \\
\hline C & 10 & High & 93.80 & a & 92.58 & a & 92.46 & a & 88.09 & a & 87.82 & a & $85.34^{a}$ & $<L O D$ \\
\hline C & 15 & Low & 95.66 & $a b$ & 95.07 & $a b$ & 88.91 & $\mathrm{ab}$ & 86.95 & $\mathrm{ab}$ & 79.26 & $\mathrm{ab}$ & 75.82 b & $<L O D$ \\
\hline C & 15 & High & 93.66 & $a b$ & 89.76 & $\mathrm{ab}$ & 82.89 & b & 82.94 & b & 81.42 & b & $81.42^{\mathrm{b}}$ & $4.08 \pm 0.31$ \\
\hline C & 20 & Low & 92.53 & $a b$ & 90.16 & $a b$ & 86.79 & $\mathrm{ab}$ & 88.05 & $\mathrm{ab}$ & 81.52 & $\mathrm{ab}$ & $75.60^{\mathrm{b}}$ & $6.15 \pm 0.24$ \\
\hline C & 20 & High & 92.34 & $a b$ & 87.68 & $a b$ & 84.24 & a & 80.87 & b & 79.00 & b & $78.18^{b}$ & $5.03 \pm 0.66$ \\
\hline D & 10 & Low & 96.45 & a & 95.81 & $a$ & 94.08 & a & 88.53 & a & 87.09 & a & $85.54^{a}$ & $<L O D$ \\
\hline D & 10 & High & 95.84 & a & 92.63 & $\mathrm{a}$ & 90.27 & a & 88.81 & a & 85.14 & a & $82.91^{\mathrm{a}}$ & $<L O D$ \\
\hline D & 15 & Low & 95.60 & a & 93.15 & ab & 84.22 & $\begin{array}{l}\mathrm{ab} \\
\mathrm{c}\end{array}$ & 83.60 & abc & 77.81 & $\mathrm{bc}$ & $74.38^{\circ}$ & $<L O D$ \\
\hline D & 15 & High & 90.70 & a & 91.06 & $\mathrm{a}$ & 84.22 & $\mathrm{ab}$ & 84.06 & $\mathrm{ab}$ & 81.65 & $\mathrm{ab}$ & $79.99^{b}$ & $3.45 \pm 0.40$ \\
\hline D & 20 & Low & 89.95 & $\mathrm{ab}$ & 87.50 & $\mathrm{ab}$ & 83.26 & $\mathrm{ab}$ & 81.94 & $\mathrm{ab}$ & 81.49 & $\mathrm{ab}$ & $76.70^{\mathrm{b}}$ & $<L O D$ \\
\hline D & 20 & High & 91.79 & ab & 90.57 & ab & 80.99 & $\mathrm{ab}$ & 79.59 & $a b$ & 77.07 & b & $75.41^{\mathrm{b}}$ & $4.56 \pm 0.30$ \\
\hline
\end{tabular}

Means of triplicate determinations

A, B - S. cerevisiae yeast and C, D - S. pastorianus yeast

${ }^{\mathrm{a}-\mathrm{b}}$ Levels with different letters in the same row are significantly different $(P<0.05)$

Sample with mark $(+)$ is significantly different $(P<0.05)$ to the sample with the same process parameters (yeast and temperature) but with high mycotoxin concentration.

Initial high contamination $1164 \pm 57 \mu \mathrm{g} / \mathrm{kg}$, Initial DON low contamination $560 \pm 49 \mu \mathrm{g} / \mathrm{kg}$

LOD DON $20 \mu \mathrm{g} / \mathrm{kg}$ 
Table 3. ZEN concentration in Saccharomyces yeast and wort fermented at different temperatures

\begin{tabular}{|c|c|c|c|c|c|c|c|c|c|c|c|c|c|c|c|}
\hline \multirow{3}{*}{$\begin{array}{c}\begin{array}{c}\text { Yeast } \\
\text { code }\end{array} \\
\mathrm{A}\end{array}$} & \multirow{3}{*}{$\begin{array}{c}\begin{array}{c}\text { Temperature } \\
\left({ }^{\circ} \mathrm{C}\right)\end{array} \\
15\end{array}$} & \multirow{3}{*}{$\begin{array}{c}\begin{array}{c}\text { Level of } \\
\text { mycotoxin }\end{array} \\
\text { Low }\end{array}$} & \multicolumn{12}{|c|}{ ZEN in wort (\%) } & \multirow{3}{*}{$\begin{array}{c}\begin{array}{c}\text { Yeast } \\
(\%)\end{array} \\
7.99 \pm 2.73\end{array}$} \\
\hline & & & \multicolumn{2}{|l|}{$24 \mathrm{~h}$} & \multicolumn{2}{|l|}{$48 \mathrm{~h}$} & \multicolumn{2}{|l|}{$72 \mathrm{~h}$} & \multicolumn{2}{|l|}{$96 \mathrm{~h}$} & \multicolumn{2}{|l|}{$120 \mathrm{~h}$} & \multicolumn{2}{|c|}{$144 \mathrm{~h}$} & \\
\hline & & & 86.66 & $a b$ & 83.23 & $\mathrm{ab}$ & 81.56 & $\mathrm{ab}$ & 71.59 & b & NA & & NA & & \\
\hline A & 15 & High & 88.30 & $a b$ & 82.96 & $\mathrm{~b}$ & 78.10 & $\mathrm{bc}$ & 69.50 & c & NA & & $\mathrm{NA}$ & & $5.49 \pm 2.21$ \\
\hline A & 20 & Low & 48.81 & $\mathrm{~b}$ & 23.13 & c & 15.83 & c & 24.01 & c & NA & & $\mathrm{NA}$ & & $28.43 \pm 9.83$ \\
\hline A & 20 & High & 42.60 & $\mathrm{~b}$ & 30.84 & $\mathrm{~b}$ & 20.89 & $\mathrm{~b}$ & 25.50 & $\mathrm{~b}$ & NA & & $\mathrm{NA}$ & & $25.24 \pm 4.05$ \\
\hline A & 25 & Low & 26.85 & $\mathrm{~b}$ & 12.54 & c & 12.02 & c & 16.09 & c & NA & & NA & & $33.86 \pm 3.07$ \\
\hline A & 25 & High & 41.47 & $\mathrm{~b}$ & 13.70 & c & 12.46 & c & 9.74 & c & NA & & $\mathrm{NA}$ & & $31.97 \pm 5.59$ \\
\hline B & 15 & Low & 108.00 & ab & 77.35 & $a b c$ & 67.25 & $\mathrm{bc}$ & 58.87 & c & NA & & $\mathrm{NA}$ & & $8.53 \pm 2.41$ \\
\hline B & 15 & High & 102.83 & a & 88.33 & ab & 80.16 & $a b$ & 66.57 & b & $\mathrm{NA}$ & & $\mathrm{NA}$ & & $5.41 \pm 1.29$ \\
\hline B & 20 & Low & 45.98 & $\mathrm{~b}$ & 32.74 & $\mathrm{bc}$ & 24.21 & c & 21.63 & c & NA & & $\mathrm{NA}$ & & $19.10 \pm 2.71$ \\
\hline B & 20 & High & 44.71 & $\mathrm{~b}$ & 49.64 & $\mathrm{~b}$ & 41.05 & $\mathrm{~b}$ & 32.54 & b & NA & & $\mathrm{NA}$ & & $24.16 \pm 8.18$ \\
\hline B & 25 & Low & 44.06 & $\mathrm{~b}$ & 24.01 & c & 16.38 & c & 15.92 & c & NA & & $\mathrm{NA}$ & & $28.55 \pm 2.38$ \\
\hline B & 25 & High & 36.07 & $\mathrm{~b}$ & 33.32 & $\mathrm{~b}$ & 27.29 & $\mathrm{~b}$ & 32.95 & $\mathrm{~b}$ & NA & & $\mathrm{NA}$ & & $29.52 \pm 3.18$ \\
\hline C & 10 & Low & 91.17 & ab & 90.92 & $\mathrm{ab}$ & 72.41 & $a b$ & 62.19 & $\mathrm{~b}$ & 59.51 & b & 60.54 & b & $9.89 \pm 4.81$ \\
\hline C & 10 & High & 95.47 & a & 84.86 & $a$ & 81.20 & a & 56.62 & $\mathrm{~b}$ & 53.45 & b & 55.51 & b & $11.44 \pm 4.08$ \\
\hline C & 15 & Low & 95.54 & a & 90.04 & $\mathrm{a}$ & 76.80 & $a b$ & 56.48 & $\mathrm{bc}$ & 44.32 & c & 43.43 & c & $11.53 \pm 3.11$ \\
\hline C & 15 & High & 96.55 & a & 81.65 & $\mathrm{~b}$ & 72.65 & $\mathrm{bc}$ & 60.64 & cd & 48.02 & d & 45.56 & d & $15.63 \pm 4.35$ \\
\hline C & 20 & Low & 78.45 & ab & 74.70 & $\mathrm{ab}$ & 69.08 & $\mathrm{bc}$ & 45.22 & cd & 39.63 & d & 41.11 & d & $23.57 \pm 2.41$ \\
\hline C & 20 & High & 89.07 & ab & 84.96 & $\mathrm{~b}$ & 66.40 & c & 53.62 & cd & 44.51 & d & 44.85 & d & $19.34 \pm 5.37$ \\
\hline D & 10 & Low & 87.25 & ab & 70.71 & $\mathrm{bc}$ & 57.52 & $\mathrm{~cd}$ & 45.85 & d & 50.45 & d & 47.44 & d & $9.85 \pm 6.40$ \\
\hline D & 10 & High & 95.43 & a & 83.96 & a & 59.19 & a & 58.55 & $\mathrm{~b}$ & 45.85 & $\mathrm{~b}$ & 45.77 & $\mathrm{~b}$ & $9.5 \pm 0.67$ \\
\hline D & 15 & Low & 83.76 & $\mathrm{~b}$ & 57.58 & $\mathrm{c}$ & 45.29 & $\mathrm{~cd}$ & 45.38 & cd & 42.42 & $d+$ & 38.07 & d & $24.06 \pm 0.95$ \\
\hline D & 15 & High & 76.22 & $\mathrm{~b}$ & 50.75 & c & 41.60 & $\mathrm{~cd}$ & 39.82 & cd & 27.56 & $d+$ & 36.85 & $c d$ & $23.01 \pm 3.30$ \\
\hline D & 20 & Low & 79.68 & $\mathrm{~b}$ & 62.41 & $\mathrm{c}^{+}$ & 42.68 & d & 45.73 & d & 36.61 & d & 37.31 & d & $24.83 \pm 1.74$ \\
\hline D & 20 & High & 73.25 & $\mathrm{~b}$ & 46.63 & $\mathrm{c}^{+}$ & 35.41 & c & 41.50 & c & 33.37 & c & 33.70 & c & $19.12 \pm 3.78$ \\
\hline
\end{tabular}

Means of triplicate determinations

A, B- S. cerevisiae yeast and C, D - S. pastorianus yeast

${ }^{a-d}$ Levels with different letters in the same row are significantly different $(P<0.05)$.

Sample with mark $(+)$ is significantly different $(P<0.05)$ to the sample with the same process parameters (number of yeast and temperature) but with high mycotoxin concentration.

Initial ZEN high contamination was $440 \pm 16 \mu \mathrm{g} / \mathrm{kg}$ Initial ZEN low contamination was $284 \pm 14 \mu \mathrm{g} / \mathrm{kg}$.

LOD ZEN $2.5 \mu \mathrm{g} / \mathrm{kg}$. 
Table 4. ZEN and DON after secondary fermentation and storage of beer

\begin{tabular}{|c|c|c|c|c|c|c|c|}
\hline \multirow[b]{2}{*}{ Mycotoxin } & \multirow{2}{*}{$\begin{array}{l}\text { Mycotoxin in wort } \\
\text { after } \\
\text { double } \\
\text { fermentation (\%) }\end{array}$} & \multirow{2}{*}{$\begin{array}{l}\text { Mycotoxin } \\
\text { in yeast } \\
(\%)\end{array}$} & \multicolumn{4}{|c|}{ Mycotoxin during storage } & \multirow{2}{*}{$\begin{array}{c}\text { Total Reduction } \\
\text { (first, second } \\
\text { fermentation and } \\
\text { storage) } \\
(\%)\end{array}$} \\
\hline & & & $\begin{array}{c}1^{\text {st }} \text { week } \\
(\%)\end{array}$ & $\begin{array}{c}2^{\text {nd }} \text { week } \\
(\%)\end{array}$ & $\begin{array}{c}3^{\text {th }} \text { week } \\
(\%)\end{array}$ & $\begin{array}{c}4^{\text {th }} \text { week } \\
(\%)\end{array}$ & \\
\hline \multirow{3}{*}{ DON } & $84.87^{\mathrm{a}}$ & $5.12 \pm 2.73$ & $84.53^{a}$ & $87.12^{a}$ & $90.22^{a}$ & $88.73^{a}$ & $27.52 \pm 5.24$ \\
\hline & & & & & & & \\
\hline & $85.43^{a}$ & $4.78 \pm 0.44$ & $79.81^{a}$ & $79.22^{a}$ & $82.50^{a}$ & $76.70^{a}$ & $37.65 \pm 6.29$ \\
\hline \multirow{2}{*}{ ZEN } & $49.01^{\mathrm{a}}$ & $\begin{array}{c}27.17 \pm \\
5.54\end{array}$ & $51.45^{a}$ & $39.10^{b}$ & $45.61^{a b}$ & $47.38^{a}$ & $83.30 \pm 3.87$ \\
\hline & $63.98^{a}$ & $\begin{array}{c}21.43 \pm \\
3.22\end{array}$ & $61.00^{\mathrm{a}}$ & $66.56^{\mathrm{a}}$ & $55.80^{\mathrm{a}}$ & $57.72^{a}$ & $79.66 \pm 4.21$ \\
\hline
\end{tabular}

Means of triplicate determinations

Levels with different letters in the same row are significantly different $(P<0.05)$.

Initial DON contamination $950.76 \pm 12 \mu \mathrm{g} / \mathrm{kg}$. Initial ZEN contamination $197.34 \pm 5 \mu \mathrm{g} / \mathrm{kg}$

LOD DON $20 \mu \mathrm{g} / \mathrm{kg}$. LOD ZEN $2.5 \mu \mathrm{g} / \mathrm{kg}$. 
Table 5. Characteristics of yeasts and wort fermented with Saccharomyces yeasts at different temperatures

\begin{tabular}{|c|c|c|c|c|c|c|c|c|c|c|c|c|c|c|}
\hline $\begin{array}{c}\text { Fermentation } \\
\text { style }\end{array}$ & $\begin{array}{c}\text { Fermentation } \\
\text { temperature } \\
\left({ }^{\circ} \mathrm{C}\right)\end{array}$ & \multicolumn{2}{|r|}{ UFC final } & \multicolumn{3}{|c|}{$\begin{array}{c}\text { Ethanol produced in } \\
\text { the wort }(\%)\end{array}$} & \multicolumn{2}{|l|}{$\begin{array}{c}\text { DON } \\
\text { adsorbed } \\
\text { on yeast } \\
(\%)\end{array}$} & \multicolumn{2}{|l|}{$\begin{array}{l}\text { DON in wort } \\
\text { after } \\
\text { fermentation } \\
(\%)\end{array}$} & \multicolumn{2}{|c|}{$\begin{array}{c}\text { ZEN } \\
\text { adsorbed } \\
\text { on yeast } \\
(\%)\end{array}$} & \multicolumn{2}{|l|}{$\begin{array}{l}\text { ZEN in wort } \\
\text { after } \\
\text { fermentation } \\
(\%)\end{array}$} \\
\hline \multirow{3}{*}{$\begin{array}{c}\text { Ale (S. } \\
\text { cerevisiae) }\end{array}$} & 15 & $10^{8}$ & $10^{8}$ & $3.41^{\circ}$ & $\mathrm{a}$ & $3.42^{a}$ & $<$ LOD & & 86.83 & & 6.86 & & 66.63 & \\
\hline & 20 & $10^{y}$ & $10^{y}$ & 3.92 & b & $3.90^{\mathrm{b}}$ & 3.02 & $\mathrm{~b}$ & 78.57 & $a b$ & 24.23 & b & 23.94 & c \\
\hline & 25 & $10^{y}$ & $10^{y}$ & 4.19 & c & $4.11^{c}$ & 2.89 & b & 76.88 & b & 30.97 & c & 18.13 & $\mathrm{c}$ \\
\hline \multirow{3}{*}{$\begin{array}{c}\text { Lager (S. } \\
\text { pastorianus) }\end{array}$} & 10 & $10^{8}$ & $10^{8}$ & 2.79 & d & $2.71^{d}$ & $<L O D$ & & 84.08 & $\mathrm{ab}$ & 10.17 & $a$ & 47.38 & b \\
\hline & 15 & $10^{8}$ & $10^{8}$ & 3.47 & a & $3.51^{a}$ & 3.93 & $\mathrm{ab}$ & 77.90 & $a b$ & 18.56 & b & 41.82 & b \\
\hline & 20 & $10^{y}$ & $10^{y}$ & 3.43 & a & $3.47^{a}$ & 5.02 & a & 76.47 & b & 21.71 & b & 39.79 & $\mathrm{~b}$ \\
\hline
\end{tabular}

UFC initial $10^{6}$ for control and contaminated wort

${ }^{\mathrm{a}-\mathrm{c}}$ Levels with different letters in the same column are significantly different $(P<0.05)$.

Level with mark $(+)$ is significantly different $(P<0.05)$ with control sample

LOD ZEN $2.5 \mu \mathrm{g} / \mathrm{kg}$, LOD DON $20 \mu \mathrm{g} / \mathrm{kg}$ 